Pikó Bettina*

\title{
A POZITÍV PSZICHOLÓGIA MISSZIÓJA A MODERN TÁRSADALOMBAN
}

\section{Paradigmaváltás a társadalomtudományokban?}

\begin{abstract}
A modern kultúra jelentôsen átformálta a társadalmi valóságot, valamint az emberek életmódját, az egészséghez és betegséghez való viszonyulását. A tudományos haladás korában sokáig a problémák feltárása, a patológiás állapotok kiszúrése volt a középpontban, ami még jelentősebbé vált a 20. században a háborús és egyéb traumák hatására. A pozitív pszichológia fejlődése döntôen a második világháború után kezdődött, de fóként a 1970-es években erősödött meg. Célja azoknak a tényezóknek a felkutatása és erősítése, amelyek az egyének és közösségek jóllétét segítik elő. A védőfaktorok jelentôsége különösen a posztmodern korban nótt meg, amelyet kockázati társadalomnak is nevezünk. A pozitív egészségpszichológia kutatási eredményei hozzájárulhatnak a népegészségügyi programok hatékony megvalósításához. Ez a kelet-európai térségben különösen fontos, ahol a társadalmi folyamatok kevésbé járulnak hozzá, hogy az egyének belső kontrollját elősegítố stabil önbecsülés alakuljon ki.
\end{abstract}

Kulcsszavak: pozitív pszichológia, protektív tényezók, modernizáció, életmód

\section{A MODERN TÁRSADALOM KIHÍVÁSAI}

A modern társadalom átformálta az emberek életmódját és világnézetét, s ezzel összefüggésben a tudományhoz, valamint az egészséghez, betegséghez és jólléthez való viszonyulását is. A modernizáció ugyanis nem csak gazdasági, politikai és társadalmi változás, valamint tudománytechnikai haladás, hanem társadalom-lélektani fordulat is (Pikó 2003a). A társadalmi valóság olyan jelentós mértékben megváltozott, hogy átformálta a mindennapi életet, az emberek közötti viszonyulást, a társadalmi viselkedést szabályozó norma- és értékrendszert (Kiss és Pikó 2004). A megváltozott társadalmi valóság egy jelentős szempontja az értékek transzformációja. A modernizáció ugyanis elvezetett az addig egységes világnézeti rendszer felbomlásához és megteremtette az alapját egy plurális értékrendú társadalomnak, amelyben jelenleg is élünk.

\footnotetext{
* Dr. Pikó Bettina

SZTE Pszichiátriai Klinika, Magatartástudományi Csoport

6722 Szeged, Szentháromság u. 5.

E-mail: piko@nepsy.szote.u-szeged.hu
} 
A premodern életmód tehát gyökereiben más, mint a modern életstílus, hiszen ez utóbbi az egységes világkép helyett az értékek pluralizálódásával, az egyéni szemléletmódok elótérbe kerülésével, az individualizálódással és az egyének közötti viszonyok fellazulásával fémjelzett szabadságeszmény formálódásával jött létre. Mindez az egyéni és társadalmi fejlődés korábban soha nem tapasztalt ütemét hozta magával. Ugyanakkor az individualizált, fogyasztói társadalom árnyoldalai is megmutatkoztak a közösségi lét háttérbe szorulásával, a fokozott énközpontúsággal, a felgyorsult életritmus okozta stressz betegségokozó hatásaival.

A sokszínú társadalomkép termékenyítóen hatott a társadalomtudományok fejlődésére is. A mindent beszabályozó társadalmi értékrendszer megingásával és a plurális értékrend kiépülésével létrejövő színes társadalmi valóság ugyanis joggal keltette fel a társadalomtudósok érdeklódését. A társadalomtudományok modernizációbeli fejlódése szorosan összefüggött a természettudományos és technikai haladással, amely egyfajta mintaként is szolgált a humán kutatások számára, elsősorban a haladás és fejlôdés folyamatos mítoszával. A társadalomtudományok ehhez a szemlélethez igazodván kritikai szemléletmódra törekedtek, és elsósorban a diszfunkciókra, a kóros folyamatokra koncentráltak. A szociológia kritikai látásmódja jól tükrözi ezt a megközelítést, de a klinikai pszichológia is eredendóen betegségközpontú, amely döntóen a patológiás állapotok kiszưrését és kezelését tartja feladatának. Ez természetesen érthetố is, hiszen - ahogy Seligman (2002) indokolja - a kóros tünetek sürgetóek, azonnali beavatkozást igényelnek. A társadalomkutatási eredmények közül is a problémafeltáró adatok kerültek elsósorban közvetlen felhasználásra.

A tudományos haladás tehát minden esetben követi a társadalom fejlődési trendjeit. Ugyanakkor ez a hatás kétirányú, hiszen a tudományos eredmények is formálják a társadalom múködését, a társadalmi valóságot. Mostanra azonban egy olyan határvonalhoz érkeztünk, amely másfajta szemléletet kíván.

\section{A POZITÍV FORDULAT SZÜKSÉGESSÉGE}

A pozitív pszichológia előtérbe kerülését Seligman (2002) társadalom-történeti okokkal magyarázza. A 20. században a háborús és egyéb traumák megnövekedése folytán a pszichológusok még inkább a kóros magatartásformák korrigálása felé fordultak. Éppen ezzel összefüggésben felfigyeltek számos olyan egyénre is, akik a nehézségek és testi-lelki traumák 
ellenére is egészségesek maradtak, sót, a trauma sikeres feldolgozása után személyiségük pozitív irányba fejlődött. Viktor E. Frankl (1985) a koncentrációs táborok túlélési mechanizmusait vizsgálva hangsúlyozta az események értelmezésének, a sors kiteljesedésének fontosságát, amely késóbb a pozitív pszichológia egyik központi eleme lett. Késóbb a hetvenes években kezdtek el olyan gyerekeket vizsgálni, akik deviáns, patogén környezetben nevelkedtek, s ennek ellenére mentálisan egészséges felnótté váltak, jóllehet, pszichopatológiai szempontból magas kockázati hányadnak voltak kitéve. A resiliency, a rugalmasság jelensége egyfajta lelki edzettséget feltételez, s egyben felhívja a figyelmet a személyiségfejlődés egyedi mintázatainak széles spektrumára (Masten 2001). Bár a pszichiátriai epidemiológia hangsúlyozza a szülôi háttér, a családi pszichopatológia jelentôségét, alapos mérlegelés szükséges annak eldöntéséhez, hogy az ilyen családokban a gyermekeket magas rizikójú csoportba soroljuk-e, azaz címkézzük, vagy pedig másfajta mentálhigiénés fejlesztést szem elótt tartva próbáljunk a megelôzés érdekében segíteni.

A pozitív pszichológia célja tehát azoknak a tényezóknek a felkutatása és erôsítése, amelyek az egyének és közösségek jóllétét segítik eló (Seligman és Csikszentmihalyi 2000). Sheldon és King (2001) megfogalmazásában a pozitív pszichológia az ember pozitív jellemvonásainak tudománya. Itt a tudomány szót külön szeretném hangsúlyozni, ugyanis - éppen a modern társadalom sajátosságaiból kifolyólag - ennek különleges jelentósége van. Amikor a modernizáció okozta életmódváltozásról beszéltünk, az értékek pluralizálódását, az egyéni szempontok elótérbe kerülését, új, szekularizált világkép formálódását is értettük alatta. A premodern kor egységes vallásos világképe ugyanis a személyiségfejlődés meghatározó pontjait is kijelölte az egyén számára, aki - ha nem is értett mindenben egyet ezekkel az elvekkel - a társadalom normatív rendszere révén betagozódott ebbe a társadalomba, annak megannyi kényszerító elemével együtt. Csakhogy a plurális értékrendszerrel párhuzamosan ezek a vonatkoztatási pontok is elveszítették általános érvényüket, sót, a posztmodern, fogyasztói társadalom számos olyan magatartási normát hozott létre, amelyek egyenesen ellentmondanak a korábbi szempontoknak. A mértékletesség például humán erénynek számít, nemcsak a premodern értékrend, hanem a pozitív pszichológia tudományos eredményei szerint is (Seligman és Csikszentmihalyi 2000). A fogyasztói társadalom értékrendszerével azonosuló egyén azonban gyakran előnyben részesíti a szerzés mindenekfeletti normáját a mértékletességgel szemben. Mivel a racionalizációt mindenekfelett szem elótt tartó tudomány korában a premodern értékrendszert már nem vehetjük alapul, ezért a humán erények „örökérvé- 
nyú volta" többé már nem magától értetôdó, így a jelenlegi társadalomban csak a modern kutatás módszereivel igazolt eredmények szolgálnak bizonyítékként.

\section{A VÉDŐFAKTOROK MEGNÖVEKEDETT JELENTÓSÉGE A MODERN KORBAN}

Az úgynevezett rizikó- és protektív modell olyan elmélet, amely kutatásokhoz megfeleló keretet, az egészségfejlesztési programokhoz pedig empirikusan megalapozott eredményeket nyújt (Jessor 1993). A rizikófaktorok, illetve ezek kombinációja alapján megállapított rizikócsoportok azonosítása igen fontos, és a beavatkozások, illetve a megelózés megtervezéséhez nélkülözhetetlen információt szolgáltat. A kutatások sokáig elsősorban a kockázati tényezók feltérképezésére koncentráltak. A társadalomtudományok kritikai szemlélete is ezt a kockázati szemléletet kívánta meg, hiszen ezek kiiktatásával érhetô el a várva várt haladás.

Idóközben kiderült azonban, hogy számos kockázati tényezô olyan mélyen gyökerezik a társadalomban, a modern kultúrában, vagy akár az egyént körülvevő mikrokulturális térben, hogy azok megváltoztatása rendkívül nehéz és hosszadalmas. Nem véletlenül beszél Beck (1992) kockázati társadalomról. A medikalizáció jelensége is összefügg ezzel: a megnövekedett kockázati helyzetek jelentősen igénybe veszik adaptációs kapacitásunkat, amely átformálja az egészség és betegség - különösen a mentális egészség és betegség - meghatározását, értelmezését. Ennek következtében számos olyan tünetet is betegségként határozunk meg, amely a társadalom és a kultúra patogén természetéból fakad ugyan, de az egyéni viselkedés szintjén kerül diagnosztizálásra (Kovács 2004).

Mindez arra hívja fel a figyelmet, hogy elsósorban a kultúra, a modern társadalom sajátosságait kellene igazán megváltoztatni ahhoz, hogy egészségesebbek legyünk testileg és lelkileg. Az egyén hatóköre azonban a társadalmi folyamatokra csak korlátozottan terjed ki. Az egészségpszichológia célpontja az egyén, hiszen az egyén adaptációs folyamatainak segítése révén sikeresebben képes alkalmazkodni a modern élet kihívásaihoz. Ehhez természetesen ismernünk kell a kultúrát, amiben élünk, hiszen enélkül az alkalmazkodás is eredménytelen. Minden segító és fejlesztố program - akár egyéneket, akár közösségeket érint - csak akkor lehet hatékony, ha figyelembe veszi a társadalmi valóság szociokulturális sajátosságait. Ugyanakkor nem törekszik arra, hogy a rizikótényezóket erón felül megváltoztassa, hanem célja elsósorban a védőfaktorok felkutatása és erôsítése. A védőfaktorok erôsítésével ugyanis még a sokszor reményte- 
len helyzetben is képessé válhatnak az egyének arra, hogy megbirkózzanak problémáikkal (Jessor 1993).

A védelmet jelentô faktorok képesek semlegesíteni a kockázati helyzetek negatív hatásait, ahhoz hasonlóan, ahogyan a negatív érzéseket is semlegesíthetik a pozitív emóciók (Fredrickson 2001). Ahogy egy tizenévesekkel végzett kvalitatív kutatásunkban egy fiatal megfogalmazta: a drog helyett kellene valami más (Pikó és Piczil 2004). Seligman (2002) a jövőorientáltságot, a kreativitás kiélését, a szociális készségek fejlesztését javasolja, amely megakadályozhatja a fiatalokat abban, hogy a drogok felé forduljanak. A pozitív pszichológia tehát nem modern "happiology”, azaz „boldogságtan”, amely tagadja a traumák, a kockázatot jelentô helyzetek, vagy akár a negatív érzelmek létjogosultságát. Éppen ellenkezóleg, ezek sikeres feldolgozásához kutatja a pozitív beavatkozás lehetôségeit. A hiányt és a negatív élethelyzeteket valami pozitívval kell helyettesíteni. De vajon tudjuk-e, melyek a pozitív lehetóségeink? Ezt a kérdést a következóképpen is fel lehetne tenni: a modern társadalom norma- és értékrendszere mennyiben segíti elő a védôfaktorok erôsítését és a pozitív humán karakterjegyek érvényesülését?

\section{POZITÍV EGÉSZSÉGPSZICHOLÓGIA A NÉPEGÉSZSÉGÜGY SZOLGÁLATÁBAN}

A vezetô halálokok, a megbetegedési statisztikákat jellemző betegségspektrum megváltozása új kihívás elé állította a népegészségügyet (Krieger és Zierler 1995). A szív- és érrendszeri betegségek, a daganatos kórokok, a balesetek, a tápcsatorna és a légutak betegségei, a reumatikus eredetú betegségek és a mentális zavarok hátterében a biológiai okok mellett pszichoszociális, életmódbeli és a modern kultúrából eredô káros, ún. nocebo hatások állnak. Nem véletlenül beszélünk civilizációs betegségekról, hiszen e betegségek szorosan összefüggnek a civilizációs ártalmakkal, amelyek középpontjában egészségkárosító életmódunk áll.

Az életmód és az egészségmagatartás az egészségi állapot legfontosabb meghatározója mind egyéni, mind pedig közösségi szinten. A modern társadalomban általában úgy tekintünk az életmódra, mint olyan jelenségre, amely az egyén szabad akaratán múlik (Crawford 1977; Ogden 1995), a szociológiai kutatások azonban felhívják a figyelmet a társadalmi és kulturális kényszerító körülményekre is. Az életmód tehát egyaránt tükrözi az egyén személyiségét, az adott közösség sajátosságait, és a társadalmi struktúrában elfoglalt pozíció normatív jellemzóit. Kimutatták például, hogy a társadalom széles rétegeit megcélzó népegész- 
ségügyi programok sokkal több sikert érnek el a felsóbb társadalmi osztályokba tartozók körében, mert ók jobban bíznak saját belsó kontrolljukban, képességeikben, lehetőségeikben (Pikó 2002).

Látszólag tehát egyszerú az egészségpolitikusok dolga, hiszen az életmód megváltoztatása a kulcs az egészségfejlesztéshez. Az életmód gyökeres átalakítása, $\mathrm{s}$ mindenekelőtt a kontrollálása így minden népegészségügyi program középpontjában áll (Blaxter 1990). Az életmód azonban - éppen komplex, azaz egyéni, közösségi és csoportszintú meghatározottsága folytán - olyannyira átfogó jelenség, hogy módosítása rendkívül nehéz feladat (Pikó 2004). Már csak azért is, mert az egészségi állapottal kapcsolatos életmód nem elszigetelten létezik, hanem az egyének és közösségek általános és átfogó életmódjának részét alkotja. Az életmód különbözó elemei pedig egymással szoros kapcsolatban állnak, egy elemet önállóan megváltoztatni szinte lehetetlen a mögötte álló átfogó életszemlélet átformálása nélkül. Az életmód egészséget leginkább meghatározó eleme, az egészségmagatartás összefüggéseinek megismerése ezért a 21. század magatartástudományának egyik legnagyobb kihívása.

Az életmód szorosan összefügg az egyén személyiségjegyeivel, attitúdjeivel, a társadalom értékrendjének a saját jellemén átszúrődő világképével, az életról alkotott felfogásával. A pozitív pszichológia továbbmegy a védőfaktorok felkutatásánál, és a pozitív karakterjegyek azonosítását szorgalmazza, amelyek biokémiai nyelvre lefordítva is elósegítik az élethez való pozitív viszonyulást, a mentális és testi egészséget (Seligman és Csikszentmihalyi 2000). A megbocsátás mint vallásos norma a premodern értékrendszer alapvetố sajátossága volt, a posztmodern korban azonban általánosan elfogadott erény jellegét már elveszítette. Ugyanakkor a magatartás-epidemiológiai kutatásokban igazolást nyert, hogy a megbocsátás képessége egészségvédó faktor (Kaplan 1992). A megfeleló önbecsülés, mások tisztelete, a jövôorientáltság és célok követése az életben hozzásegít nemcsak mentális egészségünkhöz, hanem mindez testi egészségünk kulcsa is, hiszen ezek a beállítódások életmódunkat is formálják, társadalmi valóságunkat is megalapozzák.

A modern és posztmodern társadalomban alapvetô kérdés a magatartáskontroll (Kopp és Skrabski 1995). Ez nemcsak jóllétünk, hanem életmódunk és egészségmagatartásunk szempontjából is alapvetó, meghatározó tényezô. A magatartáskontroll megvalósulása elsősorban a belsố vagy külsó irányultságtól függ. Ahhoz, hogy sikeresen változtassunk életmódunkon, hinnünk kell abban, hogy képesek vagyunk kontrollálni döntéseinket. Ez azért is lényeges kérdés, mert Riesman (1996) a posztmodern fordulattal kapcsolatban éppen azt emeli ki, hogy a modernizációval megerósödött belsó kontroll helyébe a fogyasztói társadalomban a külsó 
kontroll lép (Pikó 2003a). A külsóleg kontrollált ember könnyebben válik bárminemú manipuláció áldozatává, mint az, aki belsóleg kontrollált módon, saját értékeihez és céljaihoz igazítva hozza meg döntéseit.

A magatartási döntéseink alapja tehát értékrendünk, céljaink és az élet értelméról alkotott nézeteink összessége. Bármennyire is távolinak túnik az egészség meghatározottsága szempontjából, mindezek döntően megszabják nemcsak egészségmagatartásunkat, az egészség értékszerepét, hanem mentális egészségünket is (Brunstein 1993; Compton 2000). Lehet, hogy az anyagi javak mint értékek elótérbe kerülése hasznos a fogyasztói társadalomban elfoglalt pozíció és a mindennapi társadalmi valóság átélése, azaz a társadalmi identitás felépítése szempontjából, azonban a kutatások szerint ezek az értékek kevésbé járulnak hozzá jóllétünkhöz és életminóségünkhöz, mint az ún. posztmateriális értékek (például a család, barátság, becsületesség, lelki béke) (Pikó in press).

Ez a néhány példa is rávilágít arra, hogy igen nagy szükség van a pozitív egészségpszichológia kutatási eredményeinek közkinccsé tételére, hiszen segít eligazodni a posztmodern, fogyasztói társadalomban, s megtalálni a valódi önmegvalósításhoz vezetố utat a számos csapdahelyzet közepette.

\section{A POZITÍV EGÉSZSÉGPSZICHOLÓGIA MISSZIÓJA KELET-EURÓPÁBAN}

Ahhoz, hogy az egészségfejlesztést a gyakorlatban sikeresen meg tudjuk valósítani, olyan kutatási eredményekre van szükség, amelyek ehhez megfeleló útmutatást nyújtanak. Ez nemcsak a pozitív pszichológia missziója, hanem - ahogy arra Seligman (2002) felhívja a figyelmet - a társadalomtudományok széles spektrumának kell átalakulnia és szemléletében megújulni. Keyes (1998) a szociológia legfontosabb feladatának a szociális jóllét, a hatékony társadalmi-kulturális alkalmazkodás mibenlétének meghatározását és vizsgálatát, azaz a társadalmi védófaktorok elemzését tartja. Mindez hatékonyan kiegészítheti a pozitív egészségpszichológia eredményeit az egyéni szintú védőfaktorok feltárásával.

E tekintetben Kelet- és Közép-Európa változó társadalmai sajátos helyzetben vannak, hiszen új szemléletú népegészségügyi programjaikban éppen a pozitív egészségpszichológia és egészségszociológia eredményei játszhatják a legfontosabb szerepet (Pikó 2004). A posztszocialista társadalmakban a népegészségügyi programok tervezésénél figyelembe kell venni a társadalom változó jellegét, s a változások okozta adaptációs nehézségeket, mind egyéni, mind pedig közösségi szinten. Ahhoz ugyan- 
is, hogy az egyének és közösségek kellóképpen motiváltak legyenek a megfeleló preventív attitúd és egészségmagatartás elsajátításához, nélkülözhetetlen az egészséges önbizalom és énhatékonyság. Egy népegészségügyi program csak akkor lehet sikeres, ha pszichikai síkon is megalapozza az attitúdváltozást. A pozitív pszichikai eróforrások elósegítik a hatékony adaptációt, míg ha az adott kultúra nem támogatja a megbirkózás hatékony formáit, az egyénekben nem alakul ki az a belsó kontroll, amely a személyiség és az egészség folyamatos fejlesztésének igazi záloga. Az ún. énreguláció jelenségében mindez benne van, amelynek alapja az optimizmus, az életcélok és a megvalósításhoz szükséges készségek megléte (Schwarzer 1999). Ez utóbbiak közül külön kiemelendók az egyének és a csoportok, közösségek együttmúködését megalapozó szociális készségek (Griffin és mtsai 2001a). Természetesen a szociális készségek alapfeltétele a személyes múködést biztosító készségek előzetes elsajátítása (Griffin és mtsai 2001b). Ha e készségek jelenlétét megvizsgáljuk a posztszocialista térségben, azt tapasztaljuk, hogy - éppen a társadalom sajátosságai miatt - e készségek deficitje alakult ki, ami a mai napig is érezteti hatását, akár munkahelyi vagy családi viszonyok között, akár nagyobb csoportokban (Pikó 2003b). Hibás volna azonban az a nézet, amely kizárólag a korábbi szocialista társadalmi folyamatoknak tulajdonítaná a szociális készségek deficitjét. A posztmodern kor individualizált társadalma sem kedvez az egyén és a közösségek harmonikus kapcsolatának, a társas készségek hatékony alkalmazásának, miközben az énhatékony viselkedésnek igen jelentôs szerepet szán az egyéni érvényesülésben (Kiss és Pikó 2004; Pikó 2003a). Kétségtelen azonban, hogy a megfelelô önbecsülés és énhatékonyság birtokában sokkal nagyobb a lehetôség harmonikus közösségi formációk megvalósítására, mint olyan csoportokban, ahol az egyének önértékelése, önbecsülése nem stabil, s ezért folyamatosan védelemre szorul.

Az önbecsülés kérdését - éppen a társadalmi-kulturális kontextus miatt - érdemes külön is nagyító alá venni. Hagyományosan a magas szintú önbecsülést pozitív jelenségként értelmezzük, amely a személyiség integrációjához járul hozzá. Az újabb nézetek szerint azonban nem az önbecsülés alacsony vagy magas foka a lényeges, hanem az önbecsülésre törekvés folyamata, amelynek során egy optimális, azaz magatartási szinten is hatékony önbecsülés mutatkozik meg (Kernis 2003). Ebben a tekintetben a mentális egészség szempontjából sokkal inkább lényeges elkülönítenünk az önbecsülés stabil és törékeny voltát, mint azt, hogy valaki alacsony vagy magas fokú önbecsüléssel jellemezhetô. Ennek szükségességét alátámasztják azok az adatok is, amelyek a problémaviselkedés, például az antiszociális, agresszív megnyilvánulások gyakoriságát a ma- 
gasabb önbecsüléssel kötik össze (Rosenberg és mtsai 1989). Az újfajta megközelítés értelmében a magas önbecsülés hátterében gyakran egy túlkompenzált, törékeny önbizalom igazolható, amelynek instabilitása veszély esetén azonnal megmutatkozik. Az ilyen - látszólag magas önbecsüléssel rendelkezó - egyének magatartási döntéseit nemegyszer önigazolási tendenciák határozzák meg, aminek komoly ára van, hiszen nem autentikus, a valódi személyiség kiteljesedését szolgáló viselkedésre ösztönöz, hanem a törékeny identitás védelmére. Ez Crocker és Park (2004) szerint aláássa a hatékony viselkedéses tanulást, az autonómiát és az énregulációt. A látszólag magas szintú önbecsülés éppen ezért nem mindig jár testi és lelki egészséggel, ha az valójában törékeny önbecsülést takar, hiszen ilyen esetekben az önigazolási folyamatokra nagyon sok odafigyelés és energia megy el.

Már az imént említett szerzópáros is felhívja a figyelmet az önbecsülés kulturális gyökereire (Crocker és Park 2004). A társadalmi valóság leképezódése az egyének mindennapi viselkedésében nyilvánul meg, ami magán hordozza az adott kultúra érték- és normarendszerének lenyomatait. A nem egyértelmú viselkedési szabályok jelentôsen hozzájárulnak az instabil identitás kialakulásához, amely megalapozza a törékeny önbecsülést (Pikó 2003a). Mindehhez hozzájárul az a sajnálatos tény is, hogy Európának ebben a térségében az önismeret és más pszichikai készségek elsajátítása és fejlesztése nem tartozott hozzá a mindennapi élet kihívásaihoz. Ebból következóen a népegészségügyi programok sem veszik figyelembe sem a pszichikai, sem pedig a társadalom-lélektani történéseket, és ezek tudományos alapú összefüggéseit. A pozitív egészségpszichológia és egészségszociológia legfontosabb feladata, sốt missziója, éppen ennek tudatosítása és gyakorlati hasznosításának előkészítése.

\section{Irodalom}

Beck, U. (1992): Risk Society: Towards a New Modernity. Sage, London.

Blaxter, M. (1990): Health and Lifestyles. Routledge, London.

Brunstein, J. C. (1993): Personal goals and subjective well-being: A longitudinal study. Journal of Personality and Social Psychology, 65: 1061-1070.

Compton, W. C. (2000): Meaningfulness as a mediator of subjective well-being. Psychological Reports, 87: 156-160.

Crawford, R. (1977): You are dangerous to your health - the ideology and politics of victim blaming. International Journal of Health Services, 7: 663-680.

Crocker, J., Park, L. E. (2004): The costly pursuit of self-esteem. Psychological Bulletin, 130: 392-414.

Frankl, V. E. (1985): Man's Search for Meaning. Simon and Schuster, New York. 
Fredrickson, B. L. (2001): The role of positive emotions in positive psychology. American Psychologist, 56: 218-226.

Griffin, K. W., Epstein, J. A., Botvin, G. J., Spoth, R. L. (2001a): Social competence and substance use among rural youth: mediating role of social benefit expectancies of use. Journal of Youth and Adolescence, 30: 485-498.

Griffin, K. W., Scheier, L. M., Botvin, G. J., Diaz, T. (2001b): Protective role of personal competence skills in adolescent substance use: psychological well-being as a mediating factor. Psychology of Addictive Behaviors, 153: 194-203.

Jessor, R. (1993): Successful adolescent development among youth in high-risk settings. American Psychologist, 48: 117-126.

Kaplan, B. H. (1992): Social health and the forgiving heart: the Type B story. Journal of Behavioral Medicine, 15: 3-14.

Kernis, M. H. (2003): Toward a conceptualization of optimal self-esteem. Psychological Inquiry, 14: 1-26.

Keyes, C. L. M. (1998): Social well-being. Social Psychology Quarterly, 63: 264-279.

Kiss A., Pikó B. (2004): Elidegenedett én a modern, fogyasztói társadalomban. Valóság, 46 (7): 57-63

Kopp M., Skrabski Á. (1995): Alkalmazott magatartástudomány. Corvinus Kiadó, Budapest.

Kovács J. (2004): Pszichiátria és medikalizáció. A pszichiatrizálás okai. Lege Artis Medicinae, 14 (7): 520-524

Krieger, N., Zierler, S. (1995): What explains the public's health? - a call for epidemiologic theory. Epidemiology, 7: 107-109.

Masten, A. S. (2001): Ordinary magic. Resilience processes in development. American Psychologist, 56: 227-238.

Ogden, J. (1995): Psychosocial theory and the creation of the risky self. Social Science and Medicine, 10: 257-265.

Pikó B. (2002): Egészségszociológia. Új Mandátum Kiadó, Budapest.

Pikó B. (2003a): Kultúra, társadalom és lélektan. Akadémiai Kiadó, Budapest.

Pikó, B. (2003b): Magatartásorvoslás - egészségfejlesztés - társadalomlélektan. Mentálhigiéné és Pszichoszomatika, 4 (1): 5-10.

Pikó, B. (2004): Interplay between self and community: A role for health psychology in Eastern Europe's public health. Journal of Health Psychology, 9: 111-120.

Pikó B. F. (in press): Adolescents' health behaviors in the light of their value orientations. Substance Use and Misuse.

Pikó, B., Piczil, M. (2004): Focusing on youth's substance use and psychosocial well-being in Hungary's post-socialist transition. Administration and Policy in Mental Health, 32: 63-71.

Riesman, D. (1996): A magányos tömeg. Polgár Kiadó, Budapest.

Rosenberg, M., Schooler, C., Schoenbach, C. (1989): Self-esteem and adolescent problems: Modeling reciprocal effects. American Sociological Review, 54: 1004-1018.

Schwarzer, R. (1999): Self-regulatory processes in the adoption and maintenance of health behaviors. The role of optimism, goals, and threats. Journal of Health Psychology, 4: 115127.

Seligman, M. E. P. (2002): Positive psychology, positive prevention, and positive therapy. In Snyder, C.R., Lopez, S. (eds.): Handbook of Positive Psychology. Oxford University Press, New York, 3-9.

Seligman, M. E. P., Csikszentmihalyi, M. (2000): Positive psychology: An introduction. American Psychologist, 55: 5-14.

Sheldon, K. M., King, L. (2001): Why positive psychology is necessary? American Psychologist, 56: 216-217. 


\section{PIKÓ, BETTINA}

\section{MISSION OF POSITIVE PSYCHOLOGY IN MODERN SOCIETY}

\section{Paradigm Shift in Social Science?}

The modern culture has brought about major changes in social reality as well as people's lifestyles and attitudes towards health and illness. In the era of scientific development, the focus has long been set on detecting problems and screening pathological conditions which became most significant in the $20^{\text {th }}$ century due to war-related and other trauma types. The development of positive psychology started after World War 2, but it was getting a strong field in the 1970s. Its main goal is to map and strengthen those factors which may contribute to individuals' and communities' well-being. The role of protective factors has become particularly significant in the postmodern era which may also be called risk society. Research results of positive health psychology may contribute to the efficient achievement of health promotion programs. This is particularly important in the Eastern European region where societal processes hardly support individuals' internal locus of control which would be necessary to developing stable self-esteem.

Keywords: positive psychology, protective factors, modernization, lifestyle 